\title{
New Column on Education
}

\author{
By John W. Farrington
}

The articles in this issue by Admiral James Watkins and Prof. Jon Sharp inaugurate an Education Column. Education aspects of ocean sciences have been an important component of The Oceanography Society focus since the Society's founding. For example, in his article Jon Sharp refers to a previous article about education and comments and responses related to that article.

Although there have been efforts by ocean sciences in the $\mathrm{K}-12$ grades for decades, Admiral Watkins provides a compelling case for substantially increasing these efforts and for the broader context of public education in general. His article draws on his breadth and depth of personal experience in the nation's science- and technology-based arenas.

The more traditional major educational efforts of ocean sciences departments, schools, and institutions are in the graduate education arena. The growing challenge of assessing graduate education in ocean sciences with a view towards diverse career options for $\mathrm{Ph} . \mathrm{D}$. graduates in particular is timely. Graduate education in the sciences in general has been the subject of several national reviews because of growing concerns about career options and the unemployment or underemployment of newly graduated Ph.Ds. As program chair for the April, 1995 Oceanography Society Meeting and encouraged by the president of The Oceanography Society, Margaret Leinen, I convened a panel, "Education in Ocean Sciences: Careers and Curricula". Jon Sharp, a member of that panel, provides his views on the topic, informed in part by the panel session.

The Education Column has a splendid launching with these two articles. Readers' comments are encouraged! 